\title{
A Closer Look at the Relationship between Academic Achievement and Language Proficiency among Iranian EFL Students
}

\author{
Rahman Sahragard \\ Shiraz University, Shiraz, Iran \\ Email: rsahragard@ hotmail.com \\ Afsaneh Baharloo \\ Shiraz University, Shiraz, Iran \\ Email: baharloo.afsaneh1@yahoo.com \\ Seyyed Mohammad Ali Soozandehfar \\ Shiraz University, Shiraz, Iran \\ Email: soozandehfar@yahoo.com
}

\begin{abstract}
This study intended to find out the relationship between Iranian college students' language proficiency and their academic achievement. To achieve this goal, 151 female and male college students majoring in English Literature at Shiraz University participated in the study. The analysis of the data obtained from the sample revealed that there is a significant positive relationship between language proficiency and academic achievement. Moreover, the results of the independent t-test indicated that male and female participants did not differ significantly with regard to their language proficiency and academic achievement. In addition, one-way ANOVA which was run to determine the impact of academic level on each of the variables understudy revealed that seniors outperformed the other levels on their language proficiency. Besides, the findings indicated that juniors significantly differ from the other three groups in terms of their academic achievement.
\end{abstract}

Index Terms - language proficiency, academic achievement, academic level

\section{INTRODUCTION}

Learning a foreign language and factors that may affect this process have attracted language researchers' attention for many years. Variables which are related to language learning in an EFL context are studied and their relationships with each other are being sought in order to enhance the learning process. It is obvious that learners are of different language proficiency levels; but, any language researcher may wonder whether proficient language learners are successful students with regard to their academic achievement or not. Maleki and Zangani (2007) believe that many students who major in English language in the Iranian universities have chosen their field of study with little capability to use the language and its components, in other words, when they begin to study, they are not proficient enough in English language use and usage. Maleki and Zangani think that when students have difficulties in understanding the contents and concepts of the course which are presented in the target language, their academic success would be affected in a negative way; in other words, less proficient language learners who have little degree of capability in language use and its components may be weak with regard to their academic achievement too. Therefore, their weakness in general English can cause a drastic impact on their academic success. However, Farhady et al., (1994) believe that though having passed some courses and being graduated, Iranian EFL students in general seem not to be as proficient and qualified in language use as might be expected; in other word, Farhady et al., think that though some Iranian EFL learners seem to be successful in achieving the materials presented in their academic courses, they can not communicate successfully in real situations. Following the similar line, Savingnon (1983) argues that communication does not only occur in the classroom but also in an indefinite variety of situations and success in a particular role depends on one's understanding of the context and on the prior experience of a similar kind (cited in Maleki \& Zangani, 2007). A proficient language learner has the sufficient capability to recognize, comprehend, or produce language elements (Farhady etal., 1994).

In order to clarify the issue and find out whether language proficiency and academic achievement are related, this study was conducted to determine the relationship between language proficiency and academic achievement in an EFL context. Accordingly, the following research questions were formulated: 
1. Is there a significant relationship between English language proficiency and academic achievement of Iranian EFL college students?

2. Are there significant differences in the students' performances on language proficiency and academic achievement with regard to their years of study?

3. Is there a significant difference between males and females' performances on the language proficiency test and their academic achievement?

\section{REVIEW OF LITERATURE}

Several studies aimed at investigating the relationship between language proficiency and academic achievement among different groups and in disparate contexts. Some of those studies have yielded positive relationships between proficiency in language use and academic success; while other studies have indicated negative relationships between the two variables under their discussions. The studies regarding the relationship between language proficiency and academic achievement are classified into two groups according to their findings. First, the studies which show a significant relationship between foreign language learners' proficiency and their academic achievement are presented. Then, brief portraits of the studies which do not support the existence of a significant relationship between foreign language learners' proficiency and their academic achievement are provided.

Burgess and Greis (1970), after studying a sample of 17 college students, found that participants' TOEFL scores did correlate significantly with their grade point average, particularly, when grades for courses requiring little English (such as art, music, and math) were deleted from the GPAs ( TOEFL with total GPA, $r=.53$; TOEFL with weighted GPA, $r$ $=.56)$.

A study done by Gue and Holdway (1973) reached a similar conclusion. They investigated the relationship between academic achievement and language proficiency among 123 Thai education majors who were tested both before and after a summer language program. The correlation between the summer TOEFL scores and GPA was 0.49 and between the fall TOEFL scores and GPA was 0.59, in which both correlations were significant at the .01 level.

In addition, Garcia-Vasquez et al. (1997) compared the academic achievement of Hispanic middle and high school students with measures of their proficiency in English. They found that there is a significantly high correlation between English proficiency and English academic achievement $(\mathrm{r}=0.84)$.

In a similar study, Bulter and Castellon-Wellington (2000) aimed at finding the relationship between academic achievement and language proficiency. They compared students' content performance to their concurrent performance on a language proficiency test. Meanwhile they measured students' academic success by means of standardized achievement tests. Their study showed that there is a significant relationship between English Language Proficiency and academic achievement (cited in Maleki \& Zangani, 2007).

In order to determine whether language proficiency affects the academic achievement of EFL students, Maleki and Zangani (2007) carried out a piece of research in which a sample of 50 students was studied. $80 \%$ of the participants were female and $20 \%$ were male. To decide on their overall language proficiency, a standardized TOEFL paper test has been used. Meanwhile students' grade point averages (GPAs) were used as the indicators of learners' academic achievement. Finally,

The result of the correlation revealed a significant relation between English language proficiency and academic achievement (GPA). The correlation coefficient of the two sets of scores was 0.48. This suggests that as English proficiency increases, so does academic success. In other words, there is a positive correlation between the two variables (Maleki \& Zangani, 2007, p. 91).

The reason for the outcomes of the aforementioned studies is the idea that when learners are more proficient in language use, they can achieve course materials better and consequently they will get higher scores; therefore, the more language proficient they are, the better they achieve in their classes. Though the previously presented pieces of research highlighted positive significant relationships between foreign language proficiency and academic achievement, the following studies have come into the result that language proficiency and academic achievement do not correlate significantly.

Hwang and Dizney (1970) studied a group of 63 Chinese graduate students at the University of Oregan. They administered a standardized TOEFL test to measure students' language proficiency; and, used their GPAs as the indicators of their academic achievement. The researchers found that there was not a significant correlation between language proficiency and academic success $(\mathrm{r}=.19)$.

In a similar study, Wilcox (1975) carried out a piece of research in which he studied two groups of foreign undergraduate students to examine the link between their high school GPA and academic success as well as their language proficiency. The study revealed a significant correlation between the high school GPAs and students' academic success $(\mathrm{r}=.50)$. But, correlations between TOEFL scores and GPAs were considerably different for the groups of students in the sample. For the group from Hong Kong, the correlation between students' language proficiency and their academic achievement was .00; however, for the group from Vietnam, the correlation between TOEFL scores and GPAs was 0.46 .

Besides, Odunzze (1982) studied 118 Nigerian students in Missouri to seek the kind of relationship that might exist between academic achievement and language proficiency. TOEFL scores were used as measures of student's 
proficiency in language use, and, their grade point averages (GPAs) were considered as indicators of their academic achievement. The results showed no significant correlation between the TOEFL and students' first year grades $(\mathrm{r}=.259)$.

Stover (1982) conducted an experiment in which 159 undergraduates and graduates at the University of Arizona participated. TOEFL scores and grades in a preuniversity program were used in the study. The results yielded conflicting outcomes: Both undergraduates and graduates with TOEFL scores of less than 500 were able to achieve at a satisfying level in their first semester. Though, while the TOEFL scores and the GPAs in the preuniversity English program were significantly related to the academic success in the case of the undergraduate students $(\mathrm{r}=.21, \mathrm{p}=.05)$, they were not significant in the case of the graduates $(\mathrm{r}=.13)$.

In addition, Stevens et al. (2000) investigated the relationship between the language and academic success of sevengrade English language learners by means of two tests: a language proficiency test and a standardized achievement test. They stated that since the correspondence between the languages of the two tests was limited, one can not consider a significant correlational relationship between the two variables under discussion.

Bayliss and Raymond (2004) also examined the link between academic success and second language proficiency in the context of two professional programs. They conducted two studies. First, they investigated the link between ESL scores on an advanced ESL test and the grade point average (GPA) which was obtained over two semesters. Second, they investigated the link between French second language scores on an advanced L2 test; finally, they came to know that there is not a significant relationship between academic achievement and second language proficiency.

However, Wayne (2006) who was interested in seeking the relationship between language proficiency and academic success came into a different conclusion. His study was investigated in the immigrant population at the general college, university of Minnesota. 57 students enrolled in his study. Participants' English language proficiencies were measured by means of standardized English language proficiency tests; and students' second year GPAs were used as indicators of their academic achievement. The results showed a negative correlation between participants' language proficiency and their academic success. Wayne thought that because of the relatively few academic challenges for graduation, many refugee students graduate from high school and enter colleges and universities with limited proficiency in academic reading and writing, as well as limited content knowledge acquisition.

\section{Methodology}

\section{A. Participants}

The participants of the study consisted of a total of 151 Iranian university students majoring in English Language and Literature. They studied English as a foreign language (EFL) at Shiraz University. There were 113 female and 38 male participants; therefore, the majority of them were female. All students were young with an age range of 18 to 28 . The subjects were selected through convenient sampling since random sampling was not much practical for this study; thus, all the students who were willing and present in the administration sessions could participate in the study. The following tables indicate how the participants are distributed in different academic levels and sex.

TABLE 1

THE PARTICIPANTS DISTRIBUTION IN DIFFERENT ACADEMIC LEVELS.

\begin{tabular}{|c|c|c|c|}
\hline Academic Level & Frequency & Percent & Cumulative Percent \\
\hline Freshman & 34 & 22,5 & 22,5 \\
\hline Sophomore & 42 & 27,8 & 50,3 \\
\hline Junior & 34 & 22,5 & 72,8 \\
\hline Senior & 41 & 27,2 & 100,0 \\
\hline Total & 151 & 100,0 & \\
\hline \multicolumn{4}{|c|}{$\begin{array}{c}\text { TABLE } 2 \\
\text { SEX }\end{array}$} \\
\hline Sex & Frequency & Percent & Cumulative Percent \\
\hline Female & 113 & 74,8 & 74,8 \\
\hline Male & 38 & 25,2 & 100,0 \\
\hline Total & 151 & 100,0 & \\
\hline
\end{tabular}

\section{B. Instruments}

A proficiency test which was a truncated version of the Test of English as a Foreign Language (TOEFL) was employed in the present study. This proficiency test included 60 items. The items are multiple choice types. The test consists of 15 structure items, 15 written expression items and 30 reading comprehension items. The test has been used in another study by Rahimi (2004) and the reliability index of the test calculated through KR-21 has been reported as 0.85 ; the criterion-related validity of this test in relation to a complete TOEFL test is 0.76 ; therefore, it has been proved that this test is reliable and valid. Rahmani (2007) also applied this test in his study. The reliability of the test Rahmani 
calculated through KR-21 has been 0.85 . In the present study the reliability estimate which was calculated by KurderRichardson Formula 21 turned out to be 0.854 .

\section{Procedure}

The data were collected in the Fall semester of 2007-2008 academic year. The subjects were requested to take the proficiency test during their regular class time and without a time limit. Having collected the prerequisite data the procedure of which was explained above, permission was sought from the Department of Foreign Languages and Linguistics of Shiraz University to use the grade point averages (GPAs) of the subjects under the study in the current semester as the indicator of their academic achievement. In order to achieve the goals of this study in seeking the relationship among variables in this specific context, the data gathered were analyzed by the following statistical methods using SPSS software. First, descriptive statistics were calculated. Then, Kurder-Richardson Formula 21 was used to calculate the reliability estimate for the language proficiency test. In addition, Pearson Product Moment formula was used in order to find the correlation between variables under the study. In addition, T-test and ANOVA were utilized to find the differences among groups.

\section{RESUlts}

Utilizing the Statistical Package for Social Sciences (SPSS, the results are provided in this part. Table 3 shows descriptive statistics for students' performances on the language proficiency test.

TABLE 3.

DESCRIPTIVE STATISTICS FOR THE LANGUAGE PROFICIENCY TEST

\begin{tabular}{|l|l|l|l|l|l|}
\hline & No. of Participants & Minimum & Maximum & Mean & Std. Deviation \\
\hline Language Proficiency & 151 & 16,00 & 58,00 & 45,96 & 8,20 \\
\hline
\end{tabular}

The results in the above table show that the scores ranged from a minimum of 16 to a maximum of 58 , with an average score of 45.96 and a standard deviation of 8.20.

The scores are classified into four groups according to the participants' academic level. Table 4 shows this classification.

TABLE 4.

DESCRIPTIVE STATISTICS FOR THE PARTICIPANTS ON THE LANGUAGE PROFICIENCY TEST

\begin{tabular}{|l|l|l|l|l|l|}
\hline Academic Level & No. of Participants & Minimum & Maximum & Mean & SD \\
\hline Freshmen & 34 & 16 & 54 & 41.82 & 9.14 \\
Sophomores & 42 & 25 & 58 & 45.23 & 8.85 \\
Juniors & 34 & 27 & 57 & 44.47 & 6.99 \\
Seniors & 41 & 43 & 57 & 51.36 & 3.98 \\
\hline
\end{tabular}

According to Table 4 the results indicate that the mean of the freshmen is 41.82 with a standard deviation of 9.14 , meanwhile their scores ranged from 16 to 54 . The mean of the sophomores is 45.23 with a standard deviation of 8.85 and the range of scores is 25 to 58. The mean of juniors is 44.47 with a standard deviation of 6.99 and the scores vary from 27 to 57. Finally, seniors' average is 51.36 with a standard deviation of 3.98 and their scores range from 43 to 57 . The results show that the most variability of scores belong to the freshmen (their scores ranged from 16 to 54) and as it was expected the standard deviation related to the freshmen was higher than the other three groups. In addition, the dispersion of the seniors' scores appeared to be less than those of the other three groups (variability of their scores was from 43 to 57) and as a result they have the least standard deviation ( $\mathrm{SD}=3.98)$. Therefore, it can be concluded that the freshmen were the least homogeneous and the seniors were the most homogenous group with regard to the foreign language proficiency, the sophomores and juniors were almost in the same level of language proficiency.

TABLE 5 .

DESCRIPTIVE STATISTICS FOR TWO SEXES ON THE LANGUAGE PROFICIENCY TEST

\begin{tabular}{|l|l|l|l|l|l|}
\hline Sex & No. of Participants & Minimum & Maximum & Mean & Std. Deviation \\
\hline Males & 38 & 34 & 58 & 49.18 & 5.68 \\
& & & 58 & 44.87 & 8.65 \\
Females & 113 & 16 & 58 & \\
\hline
\end{tabular}

Table 5 reveals the descriptive statistics for the male and female participants on the language proficiency test. The mean score for males is 49.18 with a standard deviation of 5.68; while the average score of females is 44.87 with a standard deviation of 8.65 . The variability of scores among females is much more sensible (the scores range from 16 to 58) than the dispersion of scores among males (for whom the scores vary from 34 to 58), and this can be due to the inequality of the number of male and female participants. On the whole it can be concluded that males performed almost better than the females, since the males' average score is 49.18 while the females' mean is 44.87 . In order to be sure further inferential analysis will make this clear. Descriptive statistics obtained for the participants' academic achievement manifested by their GPAs utilizing SPSS software are presented in Table 6. 
TABLE 6.

DESCRIPTIVE STATISTICS FOR ACADEMIC ACHIEVEMENT

\begin{tabular}{|l|l|l|l|l|l|}
\hline & No. & Minimum & Maximum & Mean & Std. Deviation \\
\hline Academic Achievement & 151 & 13,00 & 20,00 & 16,88 & 1,40 \\
\hline
\end{tabular}

As can be seen in the Table above, the average scores for participants' academic achievement is 16.88 with a standard deviation of 1.40 , and the scores range from 13 to 20 . Figure 4.8 displays participants' academic achievement.

Table 7 shows the descriptive statistics for different groups of the participants' academic achievement.

TABLE 7.

DESCRIPTIVE STATISTICS FOR DIFFERENT GROUPS ON GPA SCORES

\begin{tabular}{|l|l|l|l|l|l|}
\hline Academic Level & No. of Participants & Minimum & Maximum & Mean & Std. Deviation \\
\hline Freshmen & 34 & 13.25 & 19.13 & 17.13 & 1.23 \\
Sophomores & 42 & 14.47 & 19.55 & 17.37 & 1.21 \\
Juniors & 34 & 13.00 & 19.12 & 15.58 & 1.42 \\
Seniors & 41 & 15.70 & 20.00 & 17.25 & 1.01 \\
\hline
\end{tabular}

According to the results which appear in Table 7, the mean score of the freshmen is 17.13 with a standard deviation of 1.23, meanwhile their scores range from 13.25 19.13. The average score of the sophomores is 17.37 with a standard deviation of 1.21 and their scores vary from 14.47 to 19.55 . The mean of juniors' GPAs is 15.58 with a standard deviation of 1.42 and their scores range from 13.00 to 19.12 . Finally, seniors' average score appeared to be 17.25 with a standard deviation of 1.01 and their GPAs vary from 15.70 to 20 . On the whole, one can notice that the juniors seemed to be weaker than the other three groups with regard to their academic achievement; since the lowest minimum score and the lowest mean belong to this group.

Table 8 reveals the descriptive statistics for males' and females' academic achievement.

TABLE 8.

DESCRIPTIVE STATISTICS FOR MALES' AND FEMALES' ACADEMIC ACHIEVEMENT

\begin{tabular}{|l|l|l|l|l|l|}
\hline Sex & No. of Participants & Minimum & Maximum & Mean & Std. Deviation \\
\hline Males & 38 & 14.14 & 20.00 & 17.15 & 1.25 \\
Females & 113 & 13.00 & 19.55 & 16.79 & 1.44 \\
\hline
\end{tabular}

According to Table 8 males' average score is 17.15 with a standard deviation of 1.25 ; besides, males' scores range from 14.14 to 20 . The mean of the females' academic achievement is 16.79 with a standard deviation of 1.44 and their scores vary from 13 to 19.55 . Therefore, the variability of males' scores tends to be similar to that of females. Figures 4.13 and 4.14 illustrate the exact performance of males and females on the academic achievement.

In order to find out the possible effect of gender on language proficiency and academic achievement scores, two independent t-tests were run and studied. Table 9 reports the results of independent t-test for the males and females' scores on the language proficiency test.

TABLE 9.

T-TEST RESULTS FOR THE MALES AND FEMALES' PERFORMANCE ON LANGUAGE PROFICIENCY

\begin{tabular}{|c|c|c|c|c|c|c|c|c|}
\hline \multirow{4}{*}{ 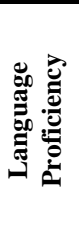 } & \multicolumn{3}{|c|}{ Levene's Test for Equality of Variances } & \multicolumn{5}{|c|}{ t-test for Equality of Means } \\
\hline & & $\mathrm{F}$ & Sig. & $\mathrm{t}$ & df & Sig. (2-tailed) & Mean Difference & Std. Error Difference \\
\hline & Equal variances assumed & 5,230 & ,024 & $-2,865$ & 149 & ,005 & $-4,308$ & 1,503 \\
\hline & Equal variances not assumed & & & $-3,503$ & 97,530 & ,001 & $-4,308$ & 1,229 \\
\hline
\end{tabular}

The first section of Table 9 gives the results of Levene's test for equality of variance between the groups. Since the sig. value obtained from the Table is less than .05 ( $\mathrm{p}=.024)$; therefore, the second line of the table which is related to the inequality of variance (equal variances not assumed) provides the information required to determine if the males and females' performance on the language proficiency test significantly differs. In addition, the sig. level in testing the equality of means appeared to be $.001(\mathrm{p}<.05)$ which reveals a significant difference in scores for males $(\mathrm{M}=49.18$, $\mathrm{SD}=5.68)$, and females $[\mathrm{M}=44.87, \mathrm{SD}=8.65 ; \mathrm{t}(97.53)=-3.50, \mathrm{p}=.001]$. However, the magnitude of the differences in the means is almost small (eta squared=.075).

Table 10 reports the results of the t-test for the males and females' scores on academic achievement. 
TABLE 10.

T-TEST RESUltS FOR THE MALES AND FEMALES' SCORES ON ACADEMIC ACHIEVEMENT

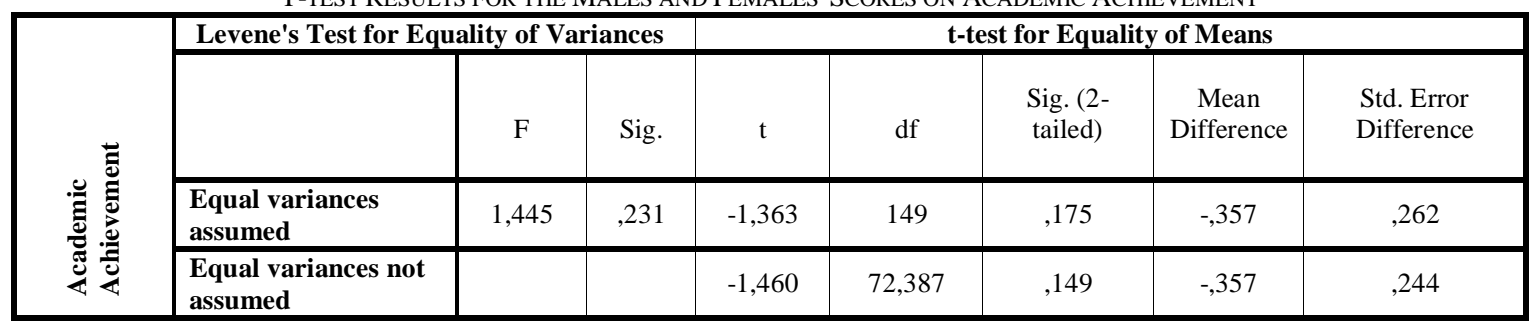

The results obtained from Table 10 show a significance level of .231 for testing the equality of variance for males and females' scores and since the sig. value is higher than .05 , one can notice that variances are assumed to be equal; therefore, the information related to the equality of variances reveals that there is no significant difference in scores for males $(\mathrm{M}=17.15, \mathrm{SD}=1.25)$, and females $[\mathrm{M}=16.79, \mathrm{SD}=1.44 ; \mathrm{t}(149)=-1.363, \mathrm{p}=.175]$. Besides, the magnitude of the differences in the means is small (eta squared=.012).

In order to determine the impact of years of university study (academic level) on the language proficiency and academic achievement two one-way ANOVAs were run separately. Table 11. reports the results of the one-way ANOVA for the language proficiency scores.

TABLE 11.

ONE-WAY ANOVA RESULTS FOR THE LANGUAGE PROFICIENCY SCORES

\begin{tabular}{|l|l|l|l|l|l|}
\hline & Sum of Squares & df & Mean Square & F & Sig. \\
\hline Between Groups & 1877,219 & 3 & 625,740 & 11,179 &, 000 \\
Within Groups & 8228,543 & 147 & 55,976 & & \\
Total & 10105,762 & 150 & & & \\
\hline
\end{tabular}

In order to conduct the one-way ANOVA which provided the results of Table 11, academic level was considered as the independent variable and the scores on the language proficiency test as the dependent variable. The results revealed statistically significant differences across the language proficiency of freshmen, sophomores, juniors and seniors $(\mathrm{F}=11.179, \mathrm{p}<0.05)$ which show that students' language proficiency tends to increase as a function of years of university study. In order to locate specifically the differences among the four groups, a post hoc (Scheffe) test was run and the results are summarized in Table 12.

TABLE 12.

SCHEFFE TEST ON THE LANGUAGE PROFICIENCY SCORES

\begin{tabular}{|l|l|l|l|l|}
\hline (I) Academic Level & $($ J) Academic Level & Mean Difference (I-J) & Std. Error & Sig. \\
\hline Freshman & Sophomore & $-3,4146$ & 1,7260 &, 275 \\
& junior & $-2,6471$ & 1,8145 &, 548 \\
& senior & $-9,5423(*)$ & 1,7354 &, 000 \\
\hline Sophomore & Freshman & 3,4146 & 1,7260 &, 275 \\
& junior &, 7675 & 1,7260 &, 978 \\
& senior & $-6,1278\left(^{*}\right)$ & 1,6425 &, 004 \\
\hline junior & Freshman & 2,6471 & 1,8145 &, 548 \\
& Sophomore &,- 7675 & 1,7260 &, 978 \\
& senior & $-6,8953(*)$ & 1,7354 &, 002 \\
\hline senior & Freshman & $9,5423(*)$ & 1,7354 &, 000 \\
& Sophomore & $6,1278(*)$ & 1,6425 &, 004 \\
& junior & $6,8953(*)$ & 1,7354 &, 002 \\
\hline
\end{tabular}

$*$ The mean difference is significant at the .05 level.

Table 12 clearly reveals that seniors out performed the other three groups. Post-hoc comparisons indicated that the mean score for seniors $(\mathrm{M}=51.36, \mathrm{SD}=3.98)$ significantly differs from that of freshmen $(\mathrm{M}=41.82, \mathrm{SD}=9.14)$, sophomores $(M=45.23, S D=8.85)$ and juniors $(M=44.47, S D=6.99)$. The effect size calculated using eta squared was 0.185 . In addition, the results indicate that sophomores and juniors did rather similarly on the test.

Table 13 presents the results of the one-way ANOVA for the academic achievement.

TABLE 13.

ONE-WAY ANOVA RESULTS FOR THE ACADEMIC ACHIEVEMENT SCORES

\begin{tabular}{|l|l|l|l|l|l|}
\hline & Sum of Squares & df & Mean Square & F & Sig. \\
\hline Between Groups & 75,016 & 3 & 25,005 & 16,740 \\
Within Groups & 219,580 & 147 & 1,494 &, 000 \\
Total & 294,596 & 150 & & & \\
\hline
\end{tabular}


Table 13 highlights statistically significant differences across academic achievement scores of first, second, third and fourth year EFL students $(\mathrm{F}=16.740, \mathrm{p}<0.05)$. In order for locating the difference between groups, a post-hoc (Scheffe) test was conducted. The results of this test are reported in Table 14.

TABLE 14.

SCHEFFE TEST ON THE ACADEMIC ACHIEVEMENT SCORES

\begin{tabular}{|c|c|c|c|c|}
\hline (I) Academic Level & (J) Academic Level & Mean Difference (I-J) & Std. Error & Sig. \\
\hline Freshman & $\begin{array}{l}\text { Sophomore } \\
\text { junior } \\
\text { senior }\end{array}$ & $\begin{array}{l}-, 2381 \\
1,5462(*) \\
-, 1249\end{array}$ & $\begin{array}{l}, 2819 \\
, 2964 \\
, 2834\end{array}$ & $\begin{array}{l}, 870 \\
, 000 \\
, 978\end{array}$ \\
\hline Sophomore & $\begin{array}{l}\text { Freshman } \\
\text { junior } \\
\text { senior }\end{array}$ & $\begin{array}{l}, 2381 \\
1,7843(*) \\
, 1132\end{array}$ & $\begin{array}{l}, 2819 \\
, 2819 \\
, 2683\end{array}$ & $\begin{array}{l}, 870 \\
, 000 \\
, 981 \\
\end{array}$ \\
\hline junior & $\begin{array}{l}\text { Freshman } \\
\text { Sophomore } \\
\text { senior }\end{array}$ & $\begin{array}{l}-1,5462(*) \\
-1,7843(*) \\
-1,6711(*) \\
\end{array}$ & $\begin{array}{l}, 2964 \\
, 2819 \\
, 2834 \\
\end{array}$ & $\begin{array}{l}, 000 \\
, 000 \\
, 000 \\
\end{array}$ \\
\hline senior & $\begin{array}{l}\text { Freshman } \\
\text { Sophomore } \\
\text { junior }\end{array}$ & $\begin{array}{l}, 1249 \\
-, 1132 \\
1,6711(*)\end{array}$ & $\begin{array}{l}, 2834 \\
, 2683 \\
, 2834\end{array}$ & $\begin{array}{l}978 \\
, 981 \\
, 000\end{array}$ \\
\hline
\end{tabular}

* The mean difference is significant at the .05 level.

Table 14 shows that juniors outperformed the other levels. Post-hoc comparisons revealed that the mean score for juniors $(\mathrm{M}=15.58, \mathrm{SD}=1.42)$ significantly differs from that of freshmen $(\mathrm{M}=17.13, \mathrm{SD}=1.23)$ sophomores $(\mathrm{M}=17.37$, $\mathrm{SD}=1.21)$, and seniors $(\mathrm{M}=17.25, \mathrm{SD}=1.01)$. The effect size calculated using eta squared appeared to be 0.25 .

In order to determine any possible relationship between language proficiency and academic achievement and to find out the strength of this relationship, Pearson correlation analysis was carried out. Table 15 displays the results of the correlational analysis.

TABLE 15.

PEARSON CORRELATION BETWEEN LANGUAGE PROFICIENCY AND ACADEMIC ACHIEVEMENT

\begin{tabular}{|l|l|l|l|l|l|}
\hline & & $\begin{array}{l}\text { Language } \\
\text { Proficiency }\end{array}$ & $\begin{array}{l}\text { Academic } \\
\text { Achievement }\end{array}$ & $\begin{array}{l}\text { Fear of } \\
\text { Success }\end{array}$ & $\begin{array}{l}\text { Imposter } \\
\text { Phenomenon }\end{array}$ \\
\hline \multirow{2}{*}{ Language Proficiency } & Pearson Correlation & 1 &, $533(* *)$ &,- 033 \\
& Sig. (2-tailed) &. &, 000 &, 685 &, 100 \\
& $\mathrm{~N}$ & 151 & 151 & 151 &, 223 \\
& Pearson Correlation &, $533(* *)$ & 1 &, 000 &,- 130 \\
Academic Achievement & Sig. (2-tailed) &, 000 &., 997 & 151 \\
& $\mathrm{~N}$ & 151 & 151 & 112 \\
\hline
\end{tabular}

Table 15 reveals a significant positive correlation between the language proficiency and the academic achievement scores $(\mathrm{r}=.53, \mathrm{p}<0.01)$, which highlights the idea that EFL students who are more proficient in English language can achieve better in their classes.

\section{DISCUSSION}

Having analyzed the collected data, the research questions can be answered and discussed in this part.

1- Is there a significant relationship between English language proficiency and academic achievement of Iranian EFL college students?

The results reported in Table 15 indicate a significant positive relationship between students' language proficiency scores and their GPAs $(\mathrm{r}=.53, \mathrm{p}<0.05)$. The figures show that this relationship is almost strong and its direction is positive, in other words, the more language proficient they are, the better they achieve in their classes. Therefore, the students who scored higher on the language proficiency test had better GPA scores. This finding of the present study is in line with those of the other studies who resulted in the idea that highlights the existence of a significant correlation between students' proficiency in English and their academic achievement. For example, Maleki and Zangani (2007) carried out a piece of research in which a sample of 50 students was studied. To decide their overall language proficiency a standardized TOEFL paper test has been used. Meanwhile students' grade point averages (GPAs) were used as the indicators of learners' academic achievement. Finally, the results of their investigation revealed a significant correlation between English language proficiency and academic achievement (GPA). The correlation coefficient of the two sets of scores was 0.48. Bulter and Castellon-Wellington (2000) who aimed at finding the relationship between academic achievement and language proficiency also found out that there was a significant relationship between English language proficiency and academic achievement. In addition, Garcia-Vasquez et al. (1997) compared the academic achievement of Hispanic middle and high school students with measures of their proficiency in English found that there is a significantly high correlation between English proficiency and English academic achievement $(\mathrm{r}=$ 
0.84). In a similar study, Gue and Holdway (1973) reached a similar conclusion they investigated the relationship between academic achievement and language proficiency among 123 Thai education majors who were tested both before and after a summer language program. The correlation between the summer TOEFL scores and GPA was 0.49 and between the fall TOEFL scores and GPA was 0.59, which both correlations were significant at the 0.01 level. Besides, Burgess and Greis (1970), after studying a sample of 17 college students, found out that participants' TOEFL scores did correlate significantly with their grade point averages, $(r=.53)$. However, the result of the present study contrasts with some other studies in which academic achievement and language proficiency do not have a significant relationship. For example, Bayliss and Raymond (2004) who examined the link between academic success and second language proficiency in the context of two professional programs came to know that there is not a significant relationship between academic achievement and second language proficiency. In addition, Stevens et al. (2000) who investigated the relationship between the language proficiency and academic success of seven-grade English language learners found no significant correlational relationship between the two variables under discussion. Furthermore, after studying 118 Nigerian students in Missouri, Odunzze (1982) found no significant correlation between the TOEFL and students' first year grades $(r=.259)$. Besides, Hwang and Dizney (1970)'s study of 63 Chinese graduate students at the University of Oregan showed that there was not a significant correlation between language proficiency and academic success $(\mathrm{r}=.19)$. However, the results of Wilcox $(1975)$ 's study both appears to be similar and contrasted with the finding of this study. Wilcox (1975) carried out a piece of research in which he studied two groups of foreign undergraduate students to examine the link between their high school GPA and their language proficiency. But, correlations between TOEFL scores and GPAs were considerably different for the groups of students in the sample. For the group from Hong Kong, the correlation between students' language proficiency and their academic achievement was .00; however, for the group from Vietnam, the correlation between TOEFL scores and GPAs was 0.46. Finally, regarding the different results obtained in disparate situations, one concludes that the field still needs more investigations.

2- Are there significant differences in the students' performances on language proficiency and academic achievement with regard to their years of study?

The results obtained from the one-way ANOVA reported in Table 11 revealed statistically significant differences across the language proficiency of freshmen, sophomores, juniors and seniors $(\mathrm{F}=11.179, \mathrm{p}<0.05)$. Table 12 indicates that seniors outperformed the other three groups. Post-hoc comparisons showed that the average score for seniors $(\mathrm{M}=51.36, \mathrm{SD}=3.98)$ significantly differs from that of freshmen $(\mathrm{M}=41.82, \mathrm{SD}=9.14)$, sophomores $(\mathrm{M}=45.23, \mathrm{SD}=8.85)$ and juniors $(M=44.47, S D=6.99)$. The effect size calculated using eta squared was 0.185 , which is acceptable. In addition, the results indicated that sophomores and juniors did rather similarly on the test. The findings showed that seniors were more proficient in English than the other three groups, therefore, years of university study affected students' language proficiency significantly. This outcome coincides with the finding of Celce-Murcia (1993)'s study. She also found that students who have been in contact with the language for several years will be more proficient in language. This may be because they have experienced more ways of learning and exposure to language use compared to those who have not had sufficient contact with the language.

Furthermore, the results of the one-way ANOVA run to see if there were any significant differences in the GPA scores of students at different years of study revealed statistically significant differences across academic achievement scores of first, second, third and fourth year EFL students $(F=16.740, p<0.05)$. The findings reported in Table 13 showed that juniors' academic achievement scores significantly differ from the other levels' GPAs. Post-hoc comparisons revealed that the mean score for juniors $(\mathrm{M}=15.58, \mathrm{SD}=1.42)$ significantly differs from that of freshmen $(\mathrm{M}=17.13, \mathrm{SD}=1.23)$ sophomores $(\mathrm{M}=17.37, \mathrm{SD}=1.21)$, and seniors $(\mathrm{M}=17.25, \mathrm{SD}=1.01)$. The effect size calculated using eta squared appeared to be 0.25 . Therefore, juniors were less successful than the other three groups with regard to their academic achievement.

3-Is there a significant difference between males and females' performances on the language proficiency test and their academic achievement?

The results reported in Table 9 revealed a significant difference in the language proficiency scores for males $(\mathrm{M}=49.18, \mathrm{SD}=5.68)$ and females $(\mathrm{M}=44.87, \mathrm{SD}=8.65 ; \mathrm{p}<0.05)$. Therefore, males are more proficient in English than females.

Moreover, the outcomes of the t-test presented in Table 10 revealed that there is no significant difference in scores for males $(M=17.15, S D=1.25)$, and females $(M=16.79, S D=1.44 ; p<.05)$ with regard to their academic achievement. In addition, the magnitude of differences in the average scores for each gender is small (eta squared=0.012). Thus, males and females do not differ in their academic achievement significantly. This finding is consistent with the outcome reported by Halawah (2006). He also found out that difference between males and females on academic achievement was not statistically significant.

\section{CONCLUSION}

The Analysis of the data proves a profound relationship between students' language proficiency and academic achievement which indicates that those who are more proficient in English can achieve academically better. Therefore, 
it is suggested that more appropriate courses which aim at improving students' proficiency in language be included in the curriculum so that students' academic achievement will promote as a result.

\section{REFERENCES}

[1] Bachman, L. F. (1990). Functional considerations in language testing (3rd ed.). Oxford: Oxford University Press.

[2] Bayliss, D., \& Raymond, P.M. (2004). The link between academic success and L2 proficiency in the context of two professional programs. The Canadian Modern Language Review, 61(1), 29-51.

[3] Best, J. W., \& Kahn, J.V. (1989). Research in education. Englewood cliffs: Prentice Hall.

[4] Burgess, T., \& Greis, N. (1970). English language proficiency and academic achievement among students of English as a second language at the college level. (ERIC Document Reproduction Service No. ED074812).

[5] Butler, F. A., \& Castellon-Wellington, M. (2000). Students' Concurrent performance on tests of English language proficiency and academic achievement. In, the validity of administrating large-scale content assessments to English language learners: An investigation from three perspectives. National Center for Research on Evaluation, Standards, and student testing. University of California, Los Angeles.

[6] Celce-Murica, M. (1993). Teaching English as a second or Foreign language. Cambridge, MA: Newbury house publishers.

[7] Doc.1: No title. Retrieved September 9, 2007, from http://www.yorku.ca/yfile/archive/index.asp?Article=5564

[8] Doc. 2: No title. Retrieved October 2, 2007, from ggsc.wnmu.edu/academic/mat/tesol/glossary.html

[9] Farhady, H. (1983). New directions for ESL proficiency testing. In J.W. Oller (Ed.), Issues in language testing research. (pp.253-268). U.S.A: Newbury House.

[10] Farhady, H., Jafarpoor, A., \& Birjandi, P. (1994). Testing language skills: From Theory to Practice. Tehran: SAMT Publications.

[11] Garcia-Vazquez, E., Vazquez, L. A., Lopez, I. C., \& Ward, W. (1997). Language proficiency and academic success: Relationships between proficiency in two languages and achievement among Mexican American students. Bilingual Research Journal, 21(4), $334-347$.

[12] Gue, L. \& Holday, E. (1973). English proficiency tests as predictors of success in graduate studies in education. Language Learning, 23, 89-103.

[13] Halawah, I. (2006). The effect of motivation, family environment, and student characteristics on academic achievement.

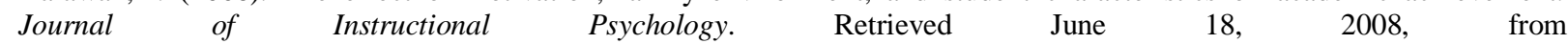
http://findarticles.com/p/articles/mi_m0FCG/is_2_33/ai_n16608929/pg_5

[14] Hwang, K. \& Dizney, H. (1970). Predictive validity of the test of English as a foreign language for Chinese graduate students at an Amarican university. Educational and Psychological Measurement, 30, 475-477.

[15] Maleki, A., \& Zangani, E. (2007). A survey on the relationship between English language proficiency and the academic achievement of Iranian EFL students. Asian EFL Journal, 9(1), 86-96.

[16] Odunze, O. (1982). Test of English as a foreign language and first year GPA of Nigerian students. Dissertation Abstracts International, 42, 3419A-3420A.

[17] Oller, J. W. (Ed.) (1983). Issues in language testing research. Rowley, Mass: Newbury House.

[18] Savignon, S. J. (1983). Communicative competence: Theory and classroom practice. Reading, Mass: Addison-Wesley.

[19] Stern, H. H. (1992). Issues and options in language teaching. Oxford: Oxford University Press.

[20] Stevens, R. A., Butler, F. A., \& Castellon-Wellington, M. (2000). Academic language and content assessment: Measuring the progress of English language learners. National Center for Research on Evaluation, Standards, and student testing. University of California, Los Angeles.

[21] Wilcox, L. (1975). The prediction of academic success of undergraduate foreign students. Dissertation Abstracts International, $35,6084 \mathrm{~B}$.

[22] Wayne, X. (2006). Language proficiency and academic success. Retrieved January 21, 2008, from http://journal.hmongvillage.com/index.php?option=com_content\&task=view\&id=46\&Itemid=54

Rahman Sahragard is assistant professor in Applied Linguistics, Department of Foreign Languages and Linguistics at Shiraz University, Shiraz, Iran. He teaches Sociolinguistics, Discourse Analysis, Pragmatics, Research Methods, and Materials Development at postgraduate level.

Afsaneh Baharloo is an English language instructor. She obtained her BA and MA degrees in English literature and ELT respectively from Shiraz University. She teaches English at both private and state universities.

Seyyed Mohammad Ali Soozandehfar is a Ph.D. student in TEFL, Department of Foreign Languages and Linguistics at Shiraz University, Shiraz, Iran. He received his BA in English Language and Literature and his MA in TEFL from Shiraz University. He teaches and translates English at different institutes. He is also skillful in doing research in TEFL. 